\title{
Studi Aliran Daya pada Saluran Distribusi 20 kV Di Kota Bandung
}

\author{
Agytia Indrajaya $^{1}$, Nasrun Hariyanto ${ }^{2}$, Teguh Arfianto $^{3}$ \\ ${ }^{1}$ Institut Teknologi Nasional \\ Jalan PH.H. Mustofa No.23, Neglasari, Cibeunying Kaler, Neglasari, Cibeunying Kaler, Kota Bandung, \\ Jawa Barat 40124, (022) 7272215 \\ ${ }^{2,3}$ Institut Teknologi Nasional \\ Jalan PH.H. Mustofa No.23, Neglasari, Cibeunying Kaler, Neglasari, Cibeunying Kaler, Kota Bandung, \\ Jawa Barat 40124, (022) 7272215 \\ agytiaindrajaya@gmail.com ${ }^{1}$,runhrt@gmail.com ${ }^{2}$, teguh.arfianto@gmail.com ${ }^{3}$
}

\begin{abstract}
Abstrak - Pertumbuhan konsumsi energi listrik di Indonesia sangat pesat, begitu pula yang terjadi di kota Bandung dengan jumlah penduduk yang mencapai $\pm 3 j u t a$ jiwa. Sehingga bisa dipastikan jika pemenuhan kebutuhan listrik di kota Bandung sangatlah penting. Oleh karena pentingnya sistem tenaga listrik harus beroperasi dengan baik, maka harus dilakukan studi aliran daya yang dapat mengetahui besaran daya, rugi-rugi, dan tegangan. Penelitian ini dilakukan dengan cara menghitung besarnya daya dan rugi-rugi pada sebuah jaringan, sehingga bisa dibandingkan dengan hasil simulasi menggunakan aplikasi ETAP. Penilitian ini difokuskan pada trafo 10 dengan penyulang CMC yang terdiri dari 5 gardu distribusi. Hasil yang didapatkan menunjukan bahwa nilai rugi-rugi total masih berada pada batas aman sesuai dengan $S$ PLN d3002-1;2007 yaitu $<5 \%$ untuk total daya sebesar $780 \mathrm{~kW}$ dan total rugi-rugi sebesar 10,5 kW.
\end{abstract}

Kata Kunci: Aliran daya, distribusi tegangan menengah, arus beban, Standard PLN (SPLN).

\section{Latar Belakang}

Perhitungan aliran daya pada suatu sistem tenaga biasanya dilakukan dengan mengasumsikan sistem tersebut dalam kondisi seimbang pada ketiga fasanya. Perhitungan aliran daya merupakan studi untuk mengetahui besaran daya, tegangan, dan rugi-rugi saluran.

Pertumbuhan konsumsi energi listrik di Indonesia sangat pesat begitu pula yang terjadi di kota Bandung apalagi dengan jumlah penduduk yang mencapai \pm 3 juta jiwa, maka oleh karena itu bisa dipastikan jika kebutuhan listrik di kota Bandung sangatlah penting. Oleh karena pentingnya sistem tenaga listrik harus beroperasi dengan baik sehingga mampu menyediakan tenaga listrik yang seekonomis mungkin dengan memperhatikan mutu dan keandalan, maka harusnya dilakukan studi-studi terkait yang dapat mendukung kelancaran operasi sistem tenaga listrik. Salah satu studi yang perlu dilakukan adalah perhitungan aliran daya.

Perhitungan aliran daya pada suatu sistem tenaga biasanya dilakukan dengan mengasumsikan sistem tersebut dalam kondisi seimbang pada ketiga fasanya. Perhitungan aliran daya merupakan studi untuk mengetahui besaran daya, tegangan, dan rugi-rugi saluran.

Dengan studi aliran daya ini diharapkan dapat menjadi acuan dalam perencanaan operasional sistem tenaga listrik serta pengembangan sistemnya untuk lebih meningkatkan kualitas energi listrik dan efisiensi yang baik saat kondisi normal maupun saat terjadi kegagalan ataupun saat perawatan peralatan daya elektrik, khususnya di wilayah kota Bandung.

TELKA, Vol.4, No.2, November 2018, pp. 121 131

ISSN (e): 2540-9123

ISSN (p): 2502-1982 


\section{Metodologi Penelitian}

Tahapan penelitian merupakan uraian tahapan yang dilakukan dalam melaksanakan penelitian. Secara umum metode pengerjaan penelitian ini dari awal hingga akhir adalah sebagai berikut.

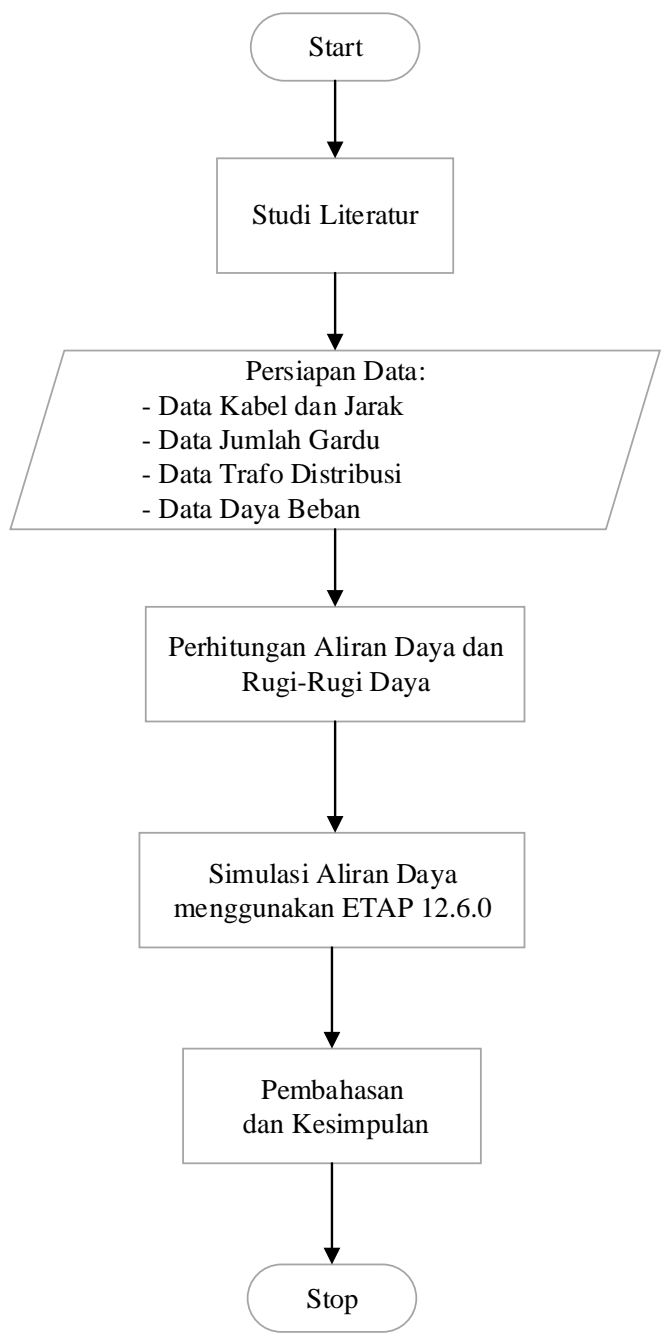

Gambar 1. Flowchart Penelitian

Pada Gambar 1 menjelaskan tentang langkah-langkah penelitian mengenai studi aliran daya pada saluran distribusi. Langkah pertama yang dilakukan adalah studi literatur dengan mempelajari buku referensi dan bahan kuliah yang mendukung dalam penyelesaian topik penelitian ini. Kemudian mengumpulkan data yang diperlukan dari tempat yang bersangkutan, data-data yang dibutuhkan adalah sebagai berikut:

1. Data Kabel ( jenis, ukuran, dan jarak)

2. Data Beban

3. Data Trafo Distribusi

4. Jumlah Gardu

Sebagian besar rugi-rugi yang terjadi pada jaringan distribusi primer adalah pada saluran distribusi dan trafo distribusi. Faktor lain yang mempengaruhi besarnya rugi-rugi di jaringan adalah ketidakseimbangan beban, karakteristik beban, dan faktor kerja beban. 


\section{Pembahasan dan Analisa}

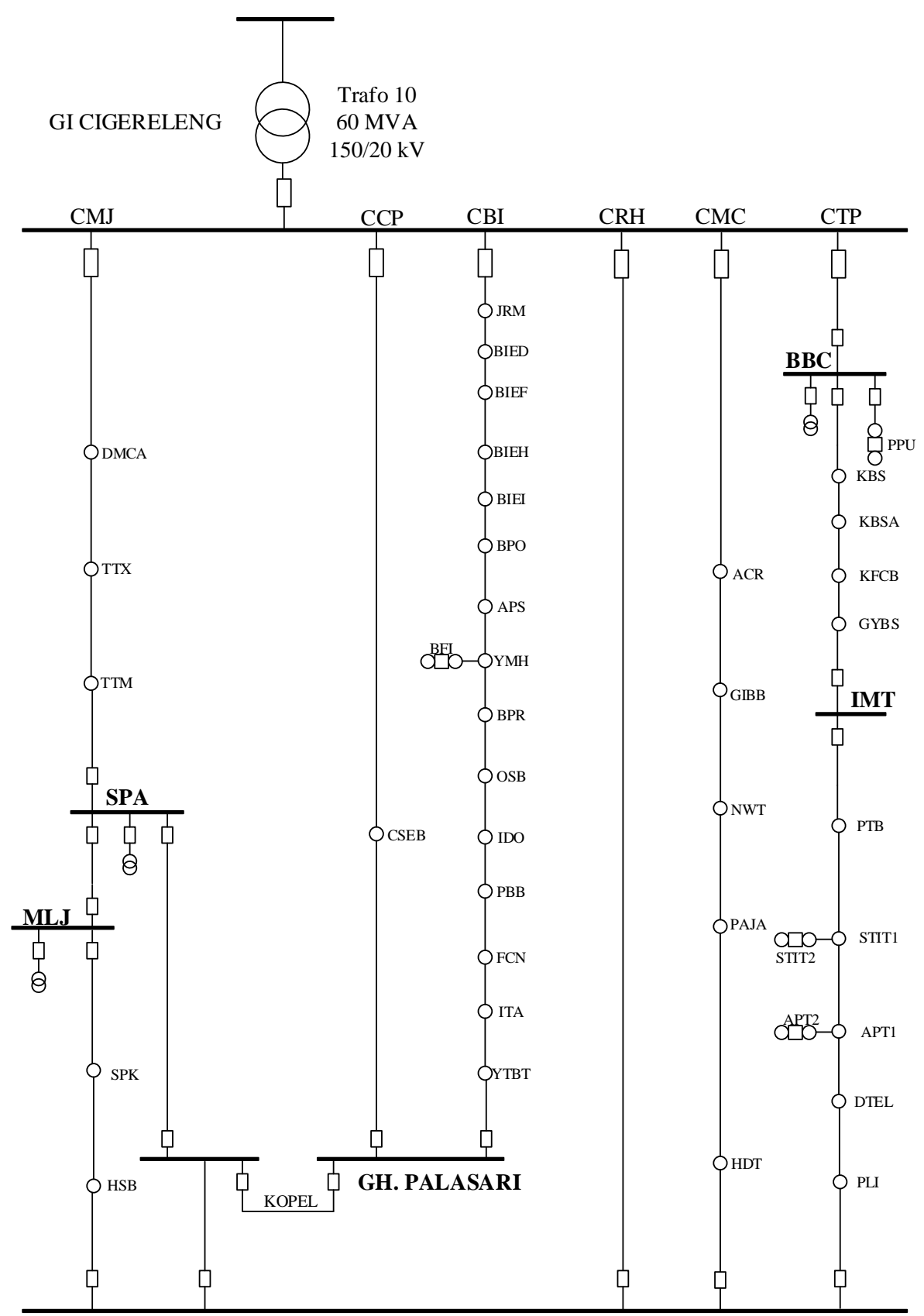

GH. MAHAMERU

Gambar 2. Jaringan Spindel GI Cigereleng - GH Mahameru

Jaringan menengah $20 \mathrm{kV}$ spindel antara GI Cigereleng GH mahameru mempunyai 6 penyulang. Jaringan ini mendapat suplai dari GI Cigereleng melalui sebuah trafo daya $150 / 20 \mathrm{kV}$, 60 MVA.

Penyulang yang terdapat pada jalur tersebut yaitu penyulang CMJ, CCP, CBI, CRH, CMC dan CTP. Diagram jaringan spindel tersebut ditunjukan pada gambar 2.

Pada keadaan operasi normal, semua saklar daya pada Gardu Hubung Palasari dan Mahameru dalam keadaan terbuka, sehingga struktur jaringan adalah radial. Sebagian besar beban yang digunakan pada jaringan spindel tersebut adalah beban industri. 
Pada masalah ini pemyulang yang akan dibahas adalah pada penyulang CMC yang terdiri dari 5 Gardu Distribusi. Pada keadaan operasi normal, semua saklar daya pada Gardu Hubung Palasari dan Mahameru dalam keadaan terbuka, sehingga struktur jaringan adalah radial. Sebagian besar beban yang digunakan pada jaringan spindel tersebut adalah beban industri.

\subsection{Data Beban}

Data beban pada penyulang CMC ini merupakan besarnya pemakaian listrik (arus) yang didapatkan dari pengukuran setiap gardu distribusi oleh pihak PLN.

Tabel 1. Data Pengukuran Arus

\begin{tabular}{|c|c|c|c|c|c|c|}
\hline \multirow{2}{*}{ JAM } & \multicolumn{3}{|c|}{ ARUS (AMPERE) } & \multicolumn{3}{c|}{ TEGANGAN (VOLT) } \\
\cline { 2 - 7 } & I FASA 1 & I FASA 2 & I FASA 3 & V FASA 1 & V FASA 2 & V FASA 3 \\
\hline 00.00 & 346 & 307 & 381 & 223 & 222 & 221 \\
\hline 01.00 & 343 & 308 & 382 & 220 & 219 & 218 \\
\hline 02.00 & 340 & 305 & 379 & 221 & 220 & 219 \\
\hline 03.00 & 339 & 304 & 378 & 222 & 221 & 220 \\
\hline 04.00 & 341 & 306 & 380 & 223 & 222 & 221 \\
\hline 05.00 & 338 & 303 & 377 & 219 & 218 & 217 \\
\hline 06.00 & 342 & 307 & 381 & 220 & 219 & 218 \\
\hline 07.00 & 340 & 305 & 379 & 221 & 220 & 219 \\
\hline 08.00 & 338 & 303 & 377 & 218 & 217 & 216 \\
\hline 09.00 & 341 & 306 & 380 & 216 & 215 & 214 \\
\hline 10.00 & 344 & 309 & 383 & 214 & 213 & 212 \\
\hline 11.00 & 346 & 311 & 385 & 217 & 216 & 215 \\
\hline 12.00 & 346 & 311 & 385 & 217 & 216 & 215 \\
\hline 13.00 & 346 & 311 & 385 & 217 & 216 & 215 \\
\hline 14.00 & 348 & 313 & 387 & 217 & 216 & 215 \\
\hline 15.00 & 344 & 309 & 383 & 217 & 217 & 211 \\
\hline 16.00 & 347 & 312 & 386 & 225 & 226 & 226 \\
\hline 17.00 & 345 & 310 & 384 & 226 & 227 & 227 \\
\hline 18.00 & 350 & 315 & 389 & 212 & 215 & 215 \\
\hline 19.00 & 351 & 316 & 390 & 228 & 228 & 228 \\
\hline 20.00 & 350 & 311 & 385 & 222 & 221 & 220 \\
\hline 21.00 & 345 & 306 & 380 & 223 & 222 & 221 \\
\hline 22.00 & 351 & 312 & 386 & 224 & 223 & 222 \\
\hline 23.00 & 349 & 310 & 384 & 222 & 221 & 220 \\
\hline 00.00 & 346 & 307 & 381 & 223 & 222 & 221 \\
\hline & & & & & & \\
\hline
\end{tabular}

\subsection{Data Jaringan}

Spesifikasi jaringan bisa dilihat pada Tabel 2 sedangkan data saluran impedansi bisa dilihat pada Tabel 3.

Tabel 2. Spesifikasi Tabel

\begin{tabular}{|c|c|c|c|}
\hline Jenis & Ukuran $\left(\mathrm{mm}^{2}\right)$ & $\mathrm{R}(\Omega / \mathrm{Km})$ & $\mathrm{L}(\mathrm{mH} / \mathrm{Km})$ \\
\hline \multirow{2}{*}{ NA2XSEBY } & $3 \times 240$ & 0.162 & 0.297 \\
\cline { 2 - 4 } & $3 \times 300$ & 0.130 & 0.289 \\
\hline
\end{tabular}

Tabel 3. Data Saluran

\begin{tabular}{|c|c|c|c|c|}
\hline Nama Antar Gardu & Tipe Kabel & Jarak & $\begin{array}{c}\text { R } \\
(\mathrm{m})\end{array}$ & $\begin{array}{c}\text { X } \\
(\text { Ohm })\end{array}$ \\
\hline E - ACR & NA2XSEBY 3X 300 & 2178 & 0,28314 & 0,197744 \\
\hline ACR - GIBB & NA2XSEBY 3X 240 & 3535 & 0,57267 & 0,329833 \\
\hline GIBB - NWT & NA2XSEBY 3X 300 & 542 & 0,07046 & 0,049209 \\
\hline NWT - PAJA & NA2XSEBY 3X 300 & 5534 & 0,71942 & 0,502442 \\
\hline PAJA - HDT & NA2XSEBY 3X 300 & 2677 & 0,34801 & 0,24305 \\
\hline
\end{tabular}




\subsection{Data Transformator Distribusi}

Data transformator distribusi ini diambil dari data trafo yang digunakan oleh pihak PLN dan Power Faktor yang biasa digunakan oleh pihak PLN antara 80-85\%. Diasumsikan Power Faktor sebesar $80 \%$ karena semakin kecil Power Faktor maka semakin besar pula losses yang terjadi.

Tabel 4. Data Kapasitas Trafo

\begin{tabular}{|c|c|c|c|c|}
\hline Gardu & $\begin{array}{c}\text { Kapasitas } \\
\text { Transformator } \\
(\text { KVA })\end{array}$ & $\begin{array}{c}\text { Rugi } \\
\text { Besi } \\
\text { (Watt) }\end{array}$ & $\begin{array}{c}\text { Tahanan } \\
\text { Tembaga } \\
(\text { Ohm })\end{array}$ & $\%$ pf \\
\hline ACR & 250 & 600 & 20,8 & 80 \\
\hline GIBB & 630 & 1300 & 6,55 & 80 \\
\hline NWT & 400 & 930 & 11,4 & 80 \\
\hline PAJA & 630 & 1300 & 6,55 & 80 \\
\hline HDT & 630 & 1300 & 6,55 & 80 \\
\hline
\end{tabular}

\subsection{Hasil Perhitungan}

Hasil perhitungan yang menggunakan contoh pada pada gardu PAJA adalah sebagai berikut:

Data Beban Gardu PAJA (Sisi Tegangan Rendah):

$\mathrm{I}_{\mathrm{TR}}=351 \mathrm{~A}$

$\mathrm{V}_{\mathrm{TR}}=228 \mathrm{~V}$

Data Beban Gardu PAJA (Sisi Tegangan Menegah):

$$
\begin{aligned}
& \mathrm{I}_{\mathrm{TM}}{ }^{\prime}=\frac{V_{2}}{V_{1}} I_{T R}=\frac{400}{20000} 351=7,02 \mathrm{~A} \\
& \mathrm{~V}_{\mathrm{TM}}{ }^{\prime}=\frac{V_{1}}{V_{2}} V_{T R}=\frac{20000}{400} 228=11400 \mathrm{~V} \\
& \mathrm{~S}_{\mathrm{TM}}{ }^{\prime}=I_{T M}{ }^{\prime} \times V_{T M}{ }^{\prime}=7,02 \times 11400=80,028 \mathrm{kVA} \\
& \mathrm{P}_{\mathrm{TM}}{ }^{\prime}=S_{T M}^{\prime} \times \cos \theta=80,028 \times 0,8=64,022 \mathrm{~kW}
\end{aligned}
$$

Data Transformator Gardu PAJA:

$\mathrm{K}_{\text {Transformator }}=630 \mathrm{kVA}$

$\mathrm{P}_{\mathrm{Fe} 3 \text { fasa }}=1300 \mathrm{Watt}$

$\mathrm{R}_{\mathrm{Cu}}=6,55 \Omega$

Rugi Besi per fasa $=\frac{1300}{3}=433,333 \mathrm{Watt}$

$\mathrm{P}_{\mathrm{Cu} 1 \text { fasa }}=I_{T M}^{2}{ }^{\prime} \times R_{C u}=\left(7,02^{2}\right) \times 6,55=322,72 \mathrm{Watt}$

$\mathrm{P}_{\text {Trafo }}=433,333+322,72=756,053 \mathrm{Watt}$

$\mathrm{S}_{\text {Trafo }}=\left(\frac{756,063 / 0,8}{1000}\right)=0,945 \mathrm{kVA}$

Daya Pada Sisi Tegangan Menengah:

$\mathrm{S}_{\mathrm{TM}}=80,028+0,945=80,973 \mathrm{kVA}$

Arus Pada Sisi Tegangan Menengah:

$\mathrm{I}_{\mathrm{TM}}=\frac{80,973 \mathrm{kVA}}{11400 \mathrm{~V}}=7,1$ Ampere 
Data Saluran antara titik NWT - PAJA:

Jenis Saluran $=$ SKTM

$1=5,534 \mathrm{~km}$

$\mathrm{r}=0,13 \Omega / \mathrm{km}$

Rugi saluran antara NWT - PAJA:

$\mathrm{P}_{\text {saluran }}=\mathrm{I}^{2} \mathrm{TM} \times \mathrm{r} \times 1=(7,1)^{2} \times 0,13 \times 5,534=36,26 \mathrm{Watt}$

$\mathrm{S}_{\text {saluran }}=\frac{36,26}{0,8}=45,325 \mathrm{VA}$

$\%$ Rugi Saluran $=\frac{36,26}{80,973 \times 10^{3}} \times 100 \%=0,0004 \%$

\subsection{Hasil Simulasi}

Hasil perhitungan aliran daya menggunakan ETAP 12.6 pada saat kondisi beban maksimum dan minimum pada setiap gardu distribusi, seperti yang ditunjukan pada Gambar 3. dan Gambar 4. dibawah ini:

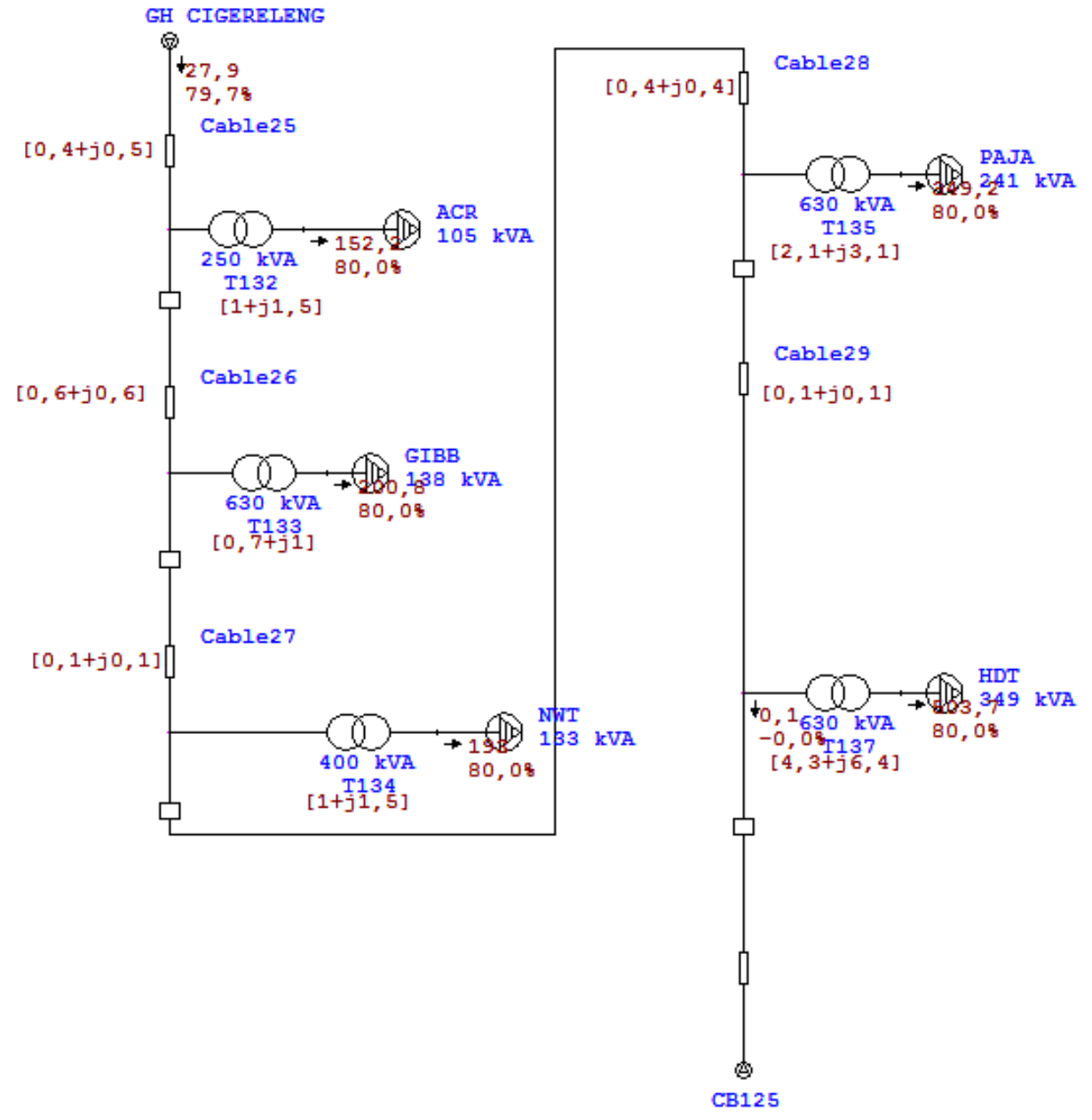

Gambar 3. Simulasi Pada Saat Beban Maksimum 


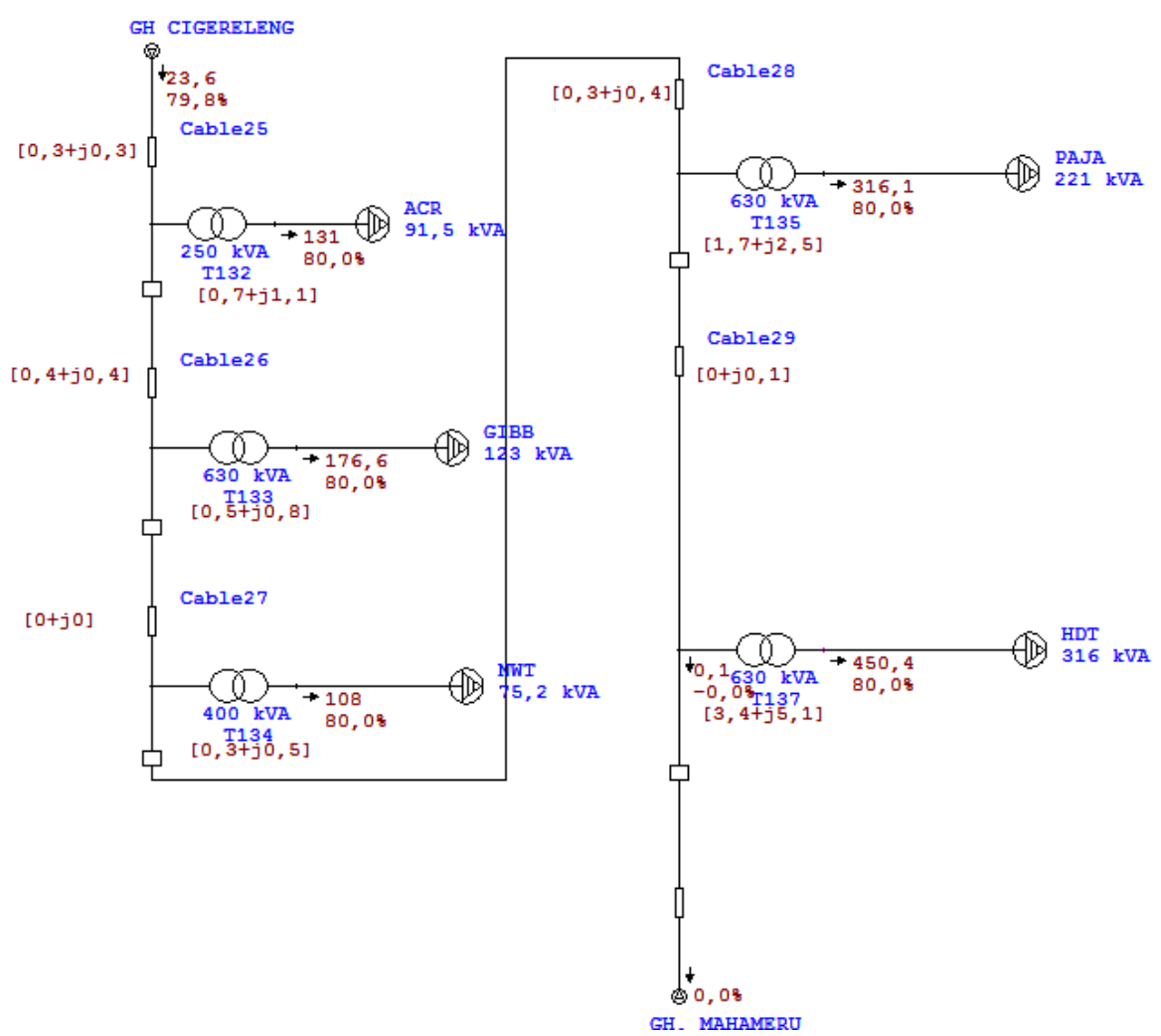

Gambar 4. Simulasi Pada Saat Beban Minimum

Dari hasil simulasi sehingga didapatkan hasil perbandingan antara nilai perhitungan dan nilai simulasi seperti yang ditunjukan pada tabel dibawah ini. Pada saat kondisi beban maksimum:

Tabel 5. Hasil Aliran Daya dengan Simulasi Etap

\begin{tabular}{|c|c|c|c|c|c|c|c|}
\hline \multicolumn{2}{|c|}{ Saluran } & \multicolumn{7}{c|}{ Maksimum } \\
\cline { 3 - 8 } \multicolumn{2}{|c|}{} & \multicolumn{2}{c|}{ Beban } & \multicolumn{2}{c|}{ Rugi-Rugi } & Arus & PF \\
\hline Dari & Ke & (kWatt) & (kvVAR) & (kWatt) & (kVAR) & (A) & $\%$ \\
\hline E & ACR & 85 & 61 & 0,4 & 0,5 & 152,2 & 80 \\
\hline ACR & GIBB & 113 & 81 & 0,6 & 0,6 & 200,8 & 80 \\
\hline GIBB & NWT & 108 & 78 & 0,1 & 0,1 & 193 & 80 \\
\hline NWT & PAJA & 195 & 140 & 0,4 & 0,4 & 349,2 & 80 \\
\hline PAJA & HDT & 279 & 210 & 0,1 & 0,1 & 503,7 & 80 \\
\hline
\end{tabular}

Tabel 6. Hasil Aliran Daya dengan Perhitungan

\begin{tabular}{|c|c|c|c|c|c|c|c|}
\hline \multicolumn{2}{|c|}{ Saluran } & \multicolumn{7}{c|}{ Maksimum } \\
\cline { 3 - 8 } \multicolumn{2}{|c|}{} & \multicolumn{2}{c|}{ Beban } & \multicolumn{2}{c|}{ Rugi-Rugi } & Arus & PF \\
\hline Dari & Ke & (kWatt) & (kVAR) & (kWatt) & (kVAR) & (A) & $\%$ \\
\hline E & ACR & 84,288 & 63,3 & 0,4 & 0,5 & 150,6 & 80 \\
\hline ACR & GIBB & 110,136 & 82,6 & 1 & 1,25 & 198,6 & 80 \\
\hline GIBB & NWT & 106,704 & 80 & 0,25 & 0,3125 & 195 & 80 \\
\hline NWT & PAJA & 192,792 & 144,4 & 0,66 & 0,825 & 352 & 80 \\
\hline PAJA & HDT & 279,536 & 209,6 & 0,11 & 0,1375 & 517 & 80 \\
\hline
\end{tabular}




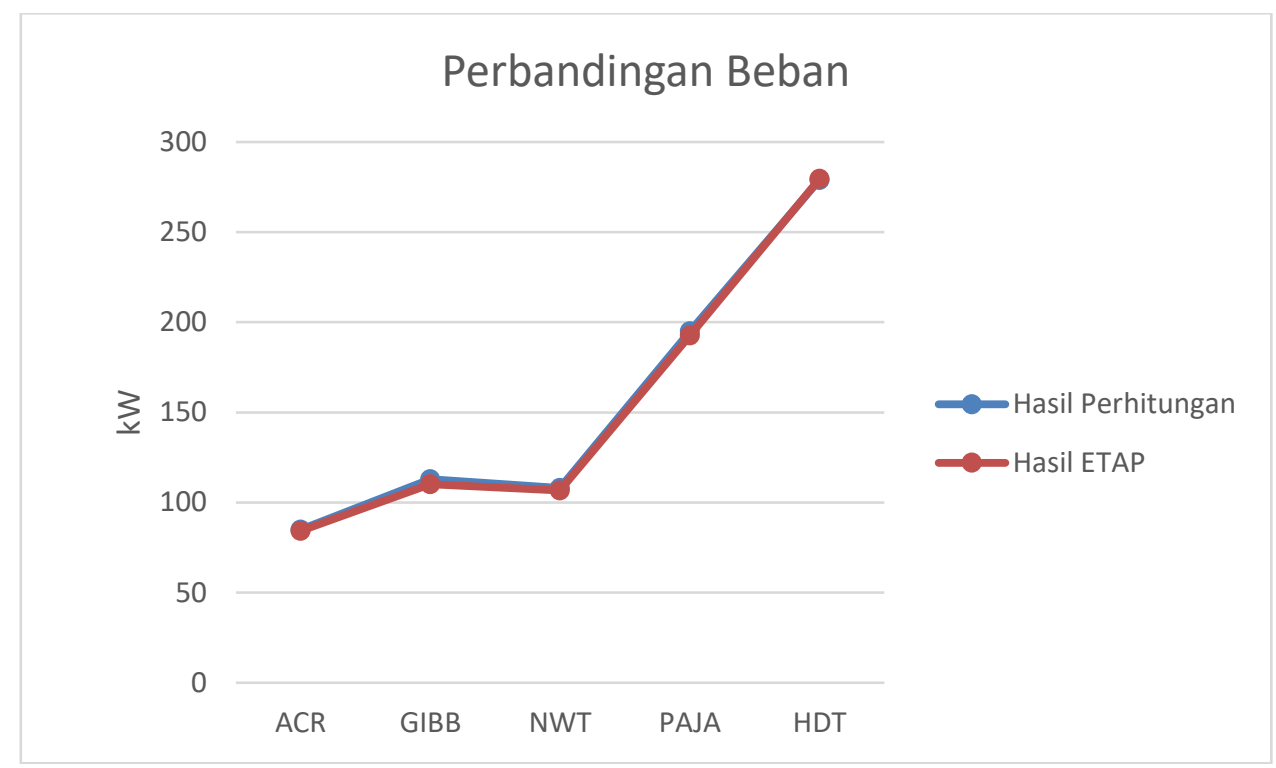

Gambar 5. Perbandingan Beban

Perbandingan Rugi-Rugi

1,2

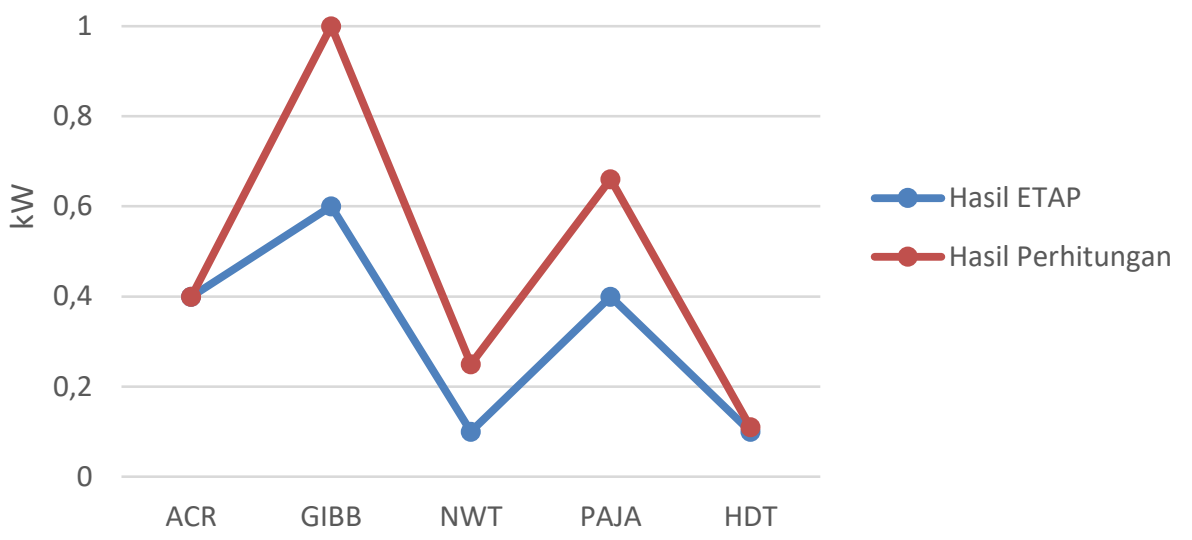

Gambar 6. Perbandingan Rugi-Rugi

Pada saat kondisi beban minimum:

Tabel 7. Hasil Aliran Daya dengan Simulasi Etap

\begin{tabular}{|c|c|c|c|c|c|c|c|}
\hline \multicolumn{2}{|c|}{ Saluran } & \multicolumn{6}{|c|}{ Minimum } \\
\cline { 3 - 8 } & \multicolumn{2}{|c|}{ Beban } & \multicolumn{2}{c|}{ Rugi-Rugi } & Arus & PF \\
\hline Dari & Ke & (kWatt) & (kVAR) & (kWatt) & (kVAR) & (A) & $\%$ \\
\hline E & ACR & 72 & 54 & 0,3 & 0,3 & 131 & 80 \\
\hline ACR & GIBB & 97 & 73 & 0,4 & 0,4 & 176,6 & 80 \\
\hline GIBB & NWT & 59 & 45 & 0 & 0 & 108 & 80 \\
\hline NWT & PAJA & 173 & 129 & 0,4 & 0,4 & 316,1 & 80 \\
\hline PAJA & HDT & 244 & 184 & 0,1 & 0,1 & 450 & 80 \\
\hline
\end{tabular}


Tabel 8. Hasil Aliran Daya dengan Perhitungan

\begin{tabular}{|c|c|c|c|c|c|c|c|}
\hline \multicolumn{2}{|c|}{ Saluran } & \multicolumn{7}{c|}{ Minimum } \\
\cline { 3 - 8 } & \multicolumn{2}{|c|}{ Beban } & \multicolumn{2}{c|}{ Rugi-Rugi } & Arus & PF \\
\hline Dari & Ke & (kWatt) & (kVAR) & (kWatt) & (kVAR) & (A) & $\%$ \\
\hline E & ACR & 73,2 & 54,9 & 0,3 & 0,375 & 1444,6 & 80 \\
\hline ACR & GIBB & 98,0136 & 73,5 & 0,66 & 0,825 & 185,6 & 80 \\
\hline GIBB & NWT & 60,1552 & 45,11 & 0,18 & 0,225 & 117,6 & 80 \\
\hline NWT & PAJA & 176,496 & 132,3 & 0,63 & 0,7875 & 345,3 & 80 \\
\hline PAJA & HDT & 252,96 & 189,72 & 0,09 & 0,1125 & 517,6 & 80 \\
\hline
\end{tabular}

\section{Perbandingan Beban}

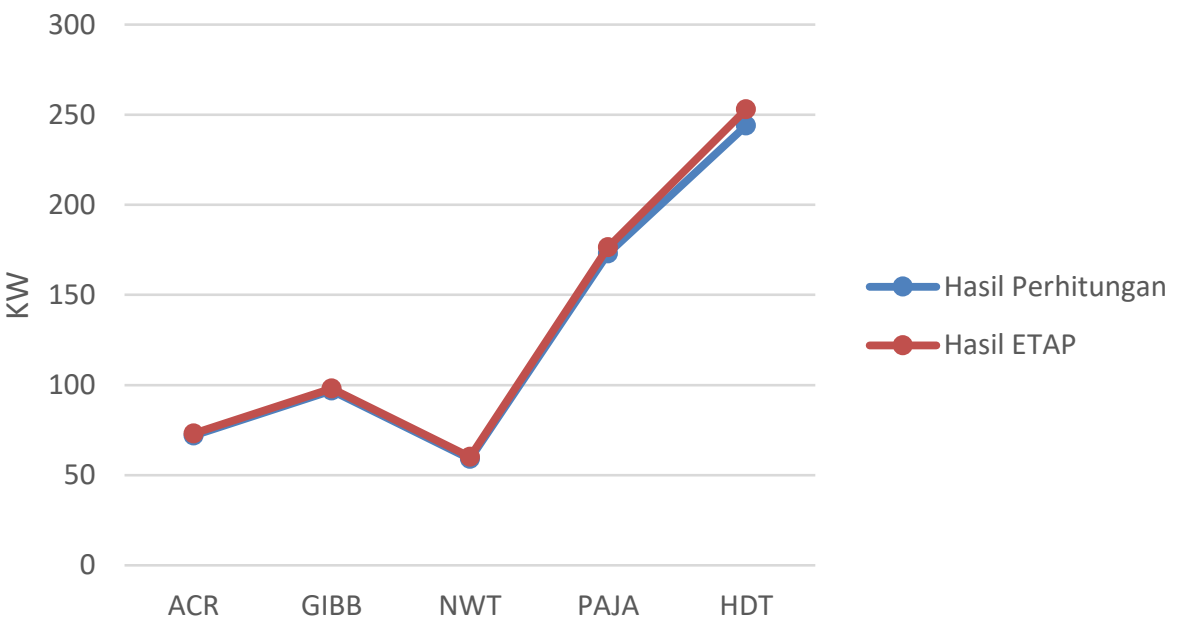

Gambar 7. Perbandingan Beban

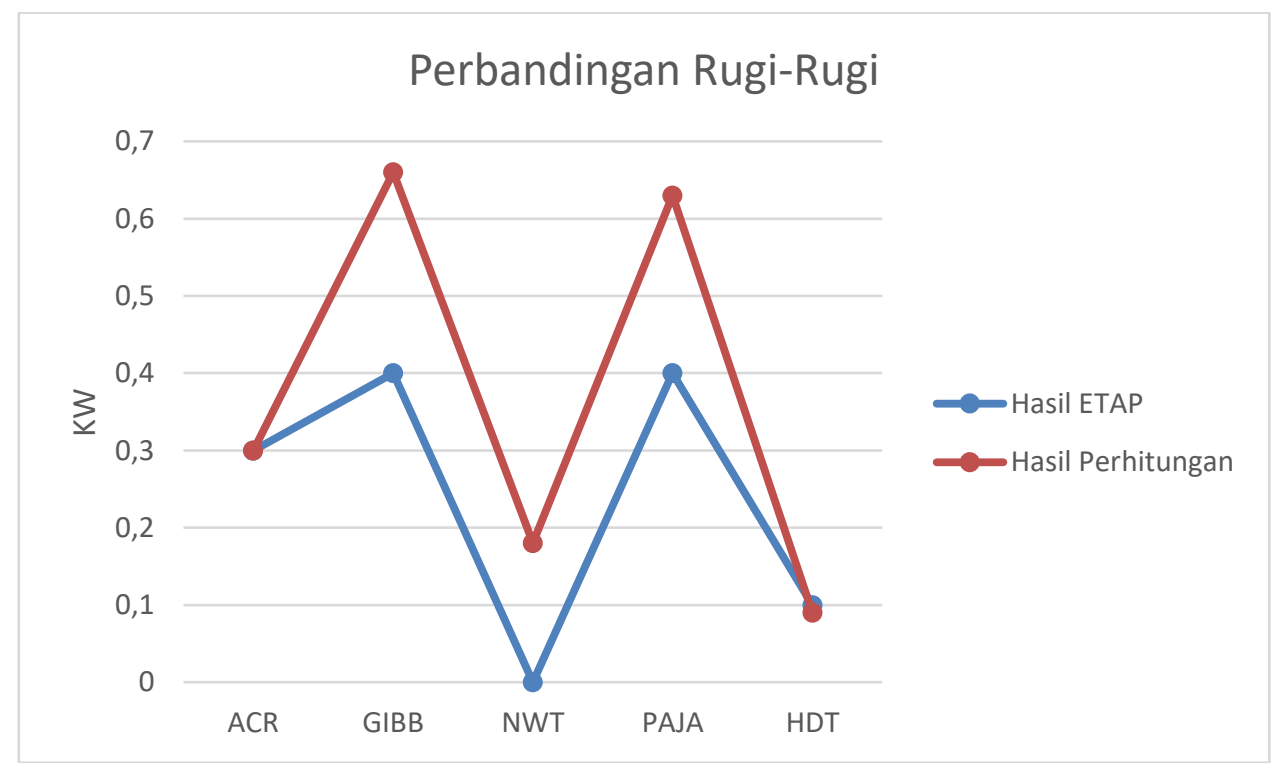

Gambar 8. Perbandingan Rugi-Rugi 
Tabel 9. Kondisi Tegangan

\begin{tabular}{|c|c|c|c|}
\hline Nama Gardu & $\begin{array}{c}\text { Operasi } \\
(\mathbf{k V})\end{array}$ & $\begin{array}{c}\text { Persentase } \\
\mathbf{\%}\end{array}$ & Kondisi \\
\hline ACR & 19,96 & 99,8 & Normal \\
\hline GIBB & 19,94 & 99,7 & Normal \\
\hline NWT & 19,94 & 99,7 & Normal \\
\hline PAJA & 19,92 & 99,6 & Normal \\
\hline HDT & 19,91 & 99,5 & Normal \\
\hline
\end{tabular}

Tabel 9. menunjukan hasil simulasi kondisi tegangan bus saat kondisi beban maksimum, diperoleh bahwa kondisi busbar dalam keadaan batas normal $\pm 10 \%$.

Dari hasil perhitungan aliran daya yang dilakukan, dapat dilihat pada Tabel 5 sampai Tabel 8, terdapat perbedaan rugi-rugi saluran antara perhitungan dan ETAP dikarenakan terdapatnya perbedaan resistansi. Resistansi yang digunakan pada ETAP menggunakan resistansi library yang tersedia pada aplikasi, sedangkan resistansi pada perhitungan menggunakan resistansi kabel yang sesuai dengan jenis kabel yang tersedia.

Tabel 10. Hasil Total Rugi Daya

\begin{tabular}{|c|c|c|c|}
\hline Nama Gardu & Beban (kW) & Rugi-Rugi (kW) & Persentase (\%) \\
\hline ACR & 85 & 1,4 & 1,6 \\
\hline GIBB & 113 & 1,3 & 1,1 \\
\hline NWT & 108 & 1,1 & 1 \\
\hline PAJA & 195 & 2,4 & 1,2 \\
\hline HDT & 279 & 4,3 & 1,5 \\
\hline Total & 780 & 10,5 & 1,3 \\
\hline
\end{tabular}

Pada Tabel diatas menunjukan total rugi-rugi yang terjadi terhadap total daya pada penyulang CMC sebesar 1,3\%. Hasil persentase masih berada dibawah Standard PT. PLN (SPLN) d3002-1;2007 sebesar $+5 \%$.

\subsection{Kesimpulan}

Hasil perhitungan dan simulasi aliran daya pada jaringan distribusi tegangan menengah $20 \mathrm{kV}$ dengan sumber Trafo 10 pada penyulang CMC terdiri dari 5 gardu distribusi.

Dari hasil simulasi aliran daya yang dilakukan penulis pada penyulang CMC dengan kondisi beban maksimum didapatkan hasil tiap-tiap Gardu Distribusi adalah beban Gardu Distribusi ACR sebesar $85 \mathrm{~kW}$ dan rugi-rugi 0,4 kW, beban Gardu Distribusi GIBB sebesar $113 \mathrm{~kW}$ dan rugi-rugi 0,6 kW, beban Gardu Distribusi NWT sebesar $108 \mathrm{~kW}$ dan rugi-rugi 0,1 kW, beban Gardu Distribusi PAJA sebesar $146 \mathrm{~kW}$ dan rugi-rugi 0,4 kW, beban Gardu Distribusi HDT sebesar $279 \mathrm{~kW}$ dan rugi-rugi 0,1 kW. Sedangkan dari hasil perhitungan untuk penyulang yang sama didapat hasil beban Gardu Distribusi ACR sebesar 84,28 kW dan rugi-rugi 0,4 kW, beban Gardu Distribusi GIBB sebesar 110,136 kW dan rugi-rugi $1 \mathrm{~kW}$, beban Gardu Distribusi NWT sebesar 106,704 kW dan rugi-rugi 
0,25 kW, beban Gardu Distribusi PAJA sebesar 192,792 kW dan rugi-rugi 0,66 kW, beban Gardu Distribusi HDT sebesar 279,536 kW dan rugi-rugi 0,11 kW.

Untuk hasil simulasi aliran daya yang dilakukan penulis pada penyulang CMC dengan kondisi beban minimum didapatkan hasil tiap-tiap Gardu Distribusi adalah beban Gardu Distribusi ACR sebesar $72 \mathrm{~kW}$ dan rugi-rugi 0,3 kW, beban Gardu Distribusi GIBB sebesar $97 \mathrm{~kW}$ dan rugi-rugi 0,4 kW, beban Gardu Distribusi NWT sebesar $59 \mathrm{~kW}$ dan rugi-rugi $0 \mathrm{~kW}$, beban Gardu Distribusi PAJA sebesar $173 \mathrm{~kW}$ dan rugi-rugi 0,4 kW, beban Gardu Distribusi HDT sebesar $244 \mathrm{~kW}$ dan rugi-rugi 0,1 kW. Sedangkan dari hasil perhitungan untuk penyulang yang sama didapat hasil beban Gardu Distribusi ACR sebesar 73,2 kW dan rugi-rugi 0,3 kW, beban Gardu Distribusi GIBB sebesar 98,01 kW dan rugi-rugi 0,6 kW, beban Gardu Distribusi NWT sebesar 60,1 kW dan rugi-rugi 0,18 kW, beban Gardu Distribusi PAJA sebesar 176,4 kW dan rugi-rugi 0,63 kW, beban Gardu Distribusi HDT sebesar 252,9 kW dan rugi-rugi 0,09 kW.

Batasan maksimum dari nilai rugi-rugi yang ingin dicapai PT. PLN menurut (SPLN) d3002-1;2007 rugi total sekitar $+5 \%$. Menurut perhitungan nilai rugi-rugi total masih berada pada batas aman.

Pada saat terjadi losses yang cukup besar maka untuk mengantisipasi hal tersebut perlu ditambahkannya trafo distribusi yang sesuai dengan kebutuhan beban, serta penambahan tarikan disisi jaringan transmisi.

\section{Daftar Rujukan}

[1]. Buku 1 (2010): Kriteria Disain Enjinering Konstruksi Jaringan Distribusi Tenaga Listrik. PT. PLN.

[2]. Dharmawan, Ari. (2000): Perhitungan Rugi-Rugi Daya dan Energi Pada Jaringan Distribusi Tegangan Menengah 20 KV Dengan Metoda Gauss-Seidel. Laporan Tugas Akhir Jurusan Teknik Elektro Institut Teknologi Nasional. Bandung.

[3]. Saadat, H. (2002): Power System Analysis, Second Editon, McGraw-Hill Primis, Singapore.

[4]. Sulistiyono, Dwi. (2011): Perbandingan Metode Gauss-Seidel, Metode Newton Raphson Dan Metode Fast Decoupled Dalam Solusi Aliran Daya. Jurnal Jurusan Teknik Elektro Universitas Diponegoro, 8-11.

[5]. Wibowo, Doni. (2008): Studi Aliran Daya Pada Subsistem Bandung Selatan Menggunakan Metode Newton Raphson. Laporan Tugas Akhir Jurusan Teknik Elektro Institut Teknologi Nasional. Bandung

[6]. Zuhal. 1998. "Dasar Teknik Listrik dan Elektronika Daya". Jakarta : Gramedia

[7]. Electric Machinery Fundamentals, by Stephen J. Chapman, second edition, Mcgraw-Hill International Edition. Electrical Engineering Series. 